raised above the stimulatory threshold. This gradual decline suggests that the implanted oestradiol is eliminated from body tissues much more slowly than thought previously (figure). We emphasise that according to the recommendations in the Data Sheet Compendium our patients were not overdosed but were treated with a conventional regimen of $50 \mathrm{mg}$ oestradiol implants reinserted roughly every six months. The mean oestradiol dose a year was $83 \mathrm{mg}$, which we would not consider to be excessive. Two of the three patients on whom data are available had plasma oestradiol values within the premenopausal range at the time of the last implant.

Our main anxiety with long lasting implants is the long term risk of endometrial malignancy. Less than three years of treatment with oral, unopposed oestrogens increases the risk of endometrial cancer ninefold for two to 14 years after treatment is withdrawn. ${ }^{10} \mathrm{We}$ suspect that prolonged unopposed stimulation by oestrogen after discontinuation of implant treatment will increase the risk of endometrial neoplasia and hence progestogen needs to be added monthly for as long as withdrawal bleeding occurs. Even then endometrial hyperplasia may arise (cases 5 and 9). This could have been due to an inadequate progestogen dose or to poor compliance. Patients with implants who fail to comply strictly with taking progestogen are known to be at an increased risk of endometrial hyperplasia: one series reported an incidence of $56 \%$."

Achieving good compliance with taking progestogen may be difficult. Symptomatic and psychological side effects are well recognised, ${ }^{+}$and there can be few women who perceive a monthly withdrawal bleed as a blessing. Implant treatment in women with an intact uterus carries the possibility of a long term commitment to taking progestogen; clinicians should advise their patients to continue taking progestogen cyclically for as long as the withdrawal bleeding continues, not for a defined period of time such as four to eight months after the last implantation.

We thank the Imperial Cancer Research Fund Laboratories, London WC2, for the financial help given to MIW.

1 Thom MH, Collins WP, Studd JWW. Hormone profiles in postmenopausal women after therapy with subcutaneous implants. Br $\mathcal{F}$ Obstet Gynaecol 1981;88:426-33.

2 Savvas M, Studd JWw, Fogelman I, Doolev M, Montgomery J, Murby B. Skeletal effects of oral oestrogen compared with subcutaneous oestrogen and testosterone in postmenopausal women. Br Med f 1988;297:331-3.

3 Persson I, Adami H-O, Bergkvist L, et al. Risk of endometrial cancer after treatment with oestrogens alone or in conjunction with progestogens: results of a prospective study. Br Med f 1989;298:147-51.

4 Magos AL, Brewster E, Singh R, O'Dowd T, Brincat M, Studd JWw. The effects of norethisterone in postmenopausal women on oestrogen replacement therapy: a model for the premenstrual syndrome. Br f Obstet Gynaecol 1986;93:1290-6

Anonymous. Data sheet compendium. London: Datapharm Publications, $1989-90: 1143$

6 British Medical Association and the Royal Pharmaceutical Society of Great Britain. British national formulary. Number 17. London: Pharmaceutical Press, 1989:254.

7 Gangar K, Cust M, Whitehead MI. Symptoms of oestrogen deficiency associated with supraphysiological plasma oestradiol concentrations in women with oestradiol implants. Br.Med f 1989;299:601-2.

8 Whitehead MI, Padwick ML, Endacott J, Pryse-Davies J. Endometrial responses to transdermal estradiol in postmenopausal women. Am $\mathcal{F}$ Obstet responses to transdermal est

9 Padwick ML, Endacott J, Whitehead MI. Efficacy, acceptability, and metabolic effects of transdermal estradiol in the management of postmen pausal women. Am f Obstet Gynecol 1985;152:1085-91.

10 Paganini-Hill A, Ross RK, Henderson BE. Endometrial cancer and patterns of use of oestrogen replacement therapy: a cohort study. $\mathrm{Br} \mathcal{F}$ Cancer 1989;59:445-7.

1 Paterson MEL, Wade-Evans T, Sturdee DW, et al. Endometrial disease after treatment with oestrogens and progestogens in the climacteric. $\mathrm{Br} \mathrm{Med} \mathcal{f}$ $1980 ; 280: 822-4$

(Accepted 13 December 1989

\title{
Omeprazole for duodenal ulceration in Crohn's disease
}

\section{R M Valori, R Cockel}

Division of Medicine, Selly Oak Hospital, Birmingham B29 6JD

R M Valori, MRCP, senior registrar in medicine R Cockel, FRCP, consultant physician

\section{Correspondence to:}

Dr R M Valori, Queen

Elizabeth Hospital,

Birmingham B15 2TH.

BrMed f 1990;300:438-9
Antroduodenal ulceration associated with Crohn's disease is fairly unresponsive to medical treatment and often leads to pyloric or duodenal obstruction that requires surgery. ${ }^{\prime}$ We describe two cases of duodenal ulceration in Crohn's disease that were unresponsive to conventional antiulcer treatment but healed when treated with omeprazole.

\section{Case reports}

Case 1-A 39 year old white woman with a 17 year history of duodenal ulceration had a right hemicolectomy for terminal ileal Crohn's disease but continued to complain of constant upper abdominal pain. Radiology showed duodenal ulceration and a recurrence of Crohn's disease in the neoterminal ileum. A reducing course of prednisolone had no effect, and her pain was not completely relieved by cimetidine (up to $2400 \mathrm{mg}$ /day), antacids, alginates, or sucralfate. She could not tolerate bismuth chelate. Endoscopy two years after the operation disclosed two active duodenal ulcers. Duodenal biopsy showed only chronic inflammatory changes. Her serum gastrin concentration was $49 \mathrm{ng} / \mathrm{l}$ (normal range $<100 \mathrm{ng} / \mathrm{l}$ ). Omeprazole $40 \mathrm{mg} /$ day completely relieved the pain within 14 days, and the ulcers had healed when endoscopy was performed four weeks later. The ulceration returned when omeprazole was stopped, although she continued to take high doses of cimetidine. Her symptoms were subsequently controlled with two month courses of omeprazole $20 \mathrm{mg} /$ day and cimetidine $1200 \mathrm{mg} /$ day alternately.

Case 2-A 30 year old white man who had had a right hemicolectomy for terminal ileal Crohn's disease at age 22 and resection of the anastomosis for recurrence with obstructive symptoms six years later developed epigastric pain. Endoscopy showed a large duodenal ulcer. Various combinations of steroids, sucralfate, antacids, bismuth chelate, and high doses of ranitidine (up to $600 \mathrm{mg} /$ day) provided incomplete relief of his symptoms. Three endoscopies performed over the next two years showed continuing ulceration and almost complete obstruction of the duodenum. Duodenal biopsy showed chronic inflammation. He was admitted to this hospital with severe pain and vomiting while being treated with ranitidine and sucralfate. Examination showed abdominal tenderness and a succussion splash. Another endoscopy confirmed ulceration with distortion and oedema of the duodenal cap. Omeprazole $40 \mathrm{mg} /$ day completely relieved the symptoms in 10 days. Endoscopy after four weeks of treatment showed a small duodenal ulcer; four weeks later the duodenum looked normal. He subsequently had occasional dyspeptic symptoms, which were controlled with antacids and infrequent courses of ranitidine.

\section{Comment}

Ulceration of the duodenal cap in patients with Crohn's disease may be peptic in origin or due to the Crohn's disease. Differentiation of the two causes by mucosal biopsy is unreliable.' Fielding and Cooke reported that peptic ulceration occurs more commonly in patients with ileal Crohn's disease than in the general population. ${ }^{2}$ Pathological data were, however, lacking and the findings were incidental in a group of patients investigated for small bowel symptoms. Duodenal 
biopsy in our patients did not show evidence of Crohn's disease, but there was unequivocal evidence of Crohn's disease elsewhere. Furthermore, the failure of symptoms in patients who do not smoke to respond to treatment suggests peptic ulceration associated with Crohn's disease. Treatment with omeprazole led to prompt relief of symptoms and complete healing of ulceration, which was confirmed by endoscopy.

Omeprazole is effective in resistant peptic ulceration, ${ }^{3}$ but there is only one report of its use in Crohn's disease. ${ }^{+} \mathrm{A}$ proton pump inhibitor, it is capable of maintaining high intragastric $\mathrm{pH}$ for long periods. ${ }^{5}$ Its effectiveness in our two patients suggests that duodenal ulceration in Crohn's disease is dependent on acid. If prolonged active ulceration can cause pyloric stenosis then intermittent omeprazole treatment might prevent this complication in patients with Crohn's disease. Our observations support the view that inhibition of acid production is more likely to heal duodenal ulceration associated with Crohn's disease than steroid treatment, which may lead to complications such as perforation or haemorrhage.

1 Weterman IT. Oral, oesophageal and gastro-duodenal Crohn's disease. In: Allan RN, Keighley MRB, Alexander-Williams J, Hawkins C, eds. Intan RN, Keigh 299-306.

2 Fielding JF, Cooke Wr. Peptic ulceration in Crohn's disease regional enteritis Gut 1970;11:998-1000.

3 Tỵtgat GNJ. Lamers CBHW, Hameeteman W, Jansen JMB, Wilson JA. Omeprazole in peptic ulcers resistant to histamine $\mathrm{H}_{2}$-receptor antagonists. Alimentary Pharmacologv and Therapeutics 1987;1:31-8.

+ Woolfson K. Greenberg GR. Symptomatic improvement of gastroduodenal Crohn's disease with omeprazole [Abstract]. Gastroenterology 1989;96:A551. Walt RP, Gomes MDFA, Wood EC, Logan LH, Pounder RE. Effect of daily oral omeprazole on 24 hour intragastric acidity. Br. Hed f 1983;287:12-t.

Accepled 28. Vorember 1989)

\section{Detection of pseudodiarrhoea by simple clinical assessment of intestinal transit rate}

\author{
Luke J D O'Donnell, Jim Virjee, \\ Kenneth W Heaton
}

Departments of Medicine and Radiology, Bristol Royal Infirmary, Bristol BS2 8HW

Luke J D O'Donnell, MD, medical registrar

Jim Virjee, FRCR, consultant radiologist

Kenneth W Heaton, FRCP, reader in medicine

Correspondence to:

Dr Heaton.

Br.Med f 1990;300:439-40

Many patients with the irritable bowel syndrome have frequent and urgent defecation that they describe as diarrhoea. Frequency and urgency can be due to an irritable rectum, as in ulcerative proctitis, ${ }^{\prime}$ and patients with these complaints mav have normal gut transit times. These patients might be said to have "pseudodiarrhoea" (faecal frequency without diarrhoea). True diarrhoea entails rapid transit through the intestine, but transit time is not measured routinely in clinics and until recently there were no accurate ways of doing so. ${ }^{2}{ }^{3}$ As different treatments are appropriate for patients with fast, normal, and slow transit a simple method of measuring transit in the outpatient clinic would be valuable. Davies $e t$ al found a close correlation between whole gut transit time and stool form scored on an eight point scale, but they studied motivated volunteers and a scientific observer examined the stools. ${ }^{+} \mathrm{We}$ investigated whether a simple record of stool form kept by the patient could be used as a guide to intestinal transit rate in the irritable bowel syndrome.

\section{Patients, methods, and results}

We devised a seven point scale in which stools were scored according to cohesion and surface cracking: 1 , separate hard lumps like nuts; 2 , sausage shaped but lumpy; 3 , like a sausage or snake but with cracks on its surface; 4 , like a sausage or snake, smooth and soft; 5 , soft blobs with clear cut edges; 6 , fluffy pieces with ragged edges, a mushy stool; 7 , watery, no solid pieces.

We recruited 30 consecutive patients ( 10 men, 20 women; ages 18-68) from a general gastroenterology outpatient department. All fulfilled the diagnostic criteria for the irritable bowel syndrome ${ }^{5}$ and consented to the study. Each patient was given a form to record the type and time of evacuation of six consecutive stools and to indicate whether the desire to defecate was urgent. The mean score for the six defecations was calculated for each patient. Whole gut and regional colonic transit times were measured simultaneously: patients swallowed 20 radio-opaque polyethylene markers on four consecutive mornings, and an abdominal radiograph was obtained on the fifth morning. Whole gut transit time was calculated as $1 \cdot 2$ times the number of markers in the abdomen and regional transit time as 1.2 times the number of markers in the region. ${ }^{3}$ In one patient with slow transit radiography was repeated on the sixth morning.

Whole gut transit time ranged from six to 108 hours. Stool frequency ranged from $0 \cdot 3$ to $5 \cdot 0 / 24 \mathrm{~h}$. There was no relation between stool frequency and whole gut transit time $(r=-0.022)$. The mean stool form score was evenly distributed, with similar numbers of patients scoring $<3,3-5$, and $>5$. Mean stool form score correlated well with whole gut transit time $(\mathrm{r}=-0.77, \mathrm{p}<0.001$; figure). Although there were

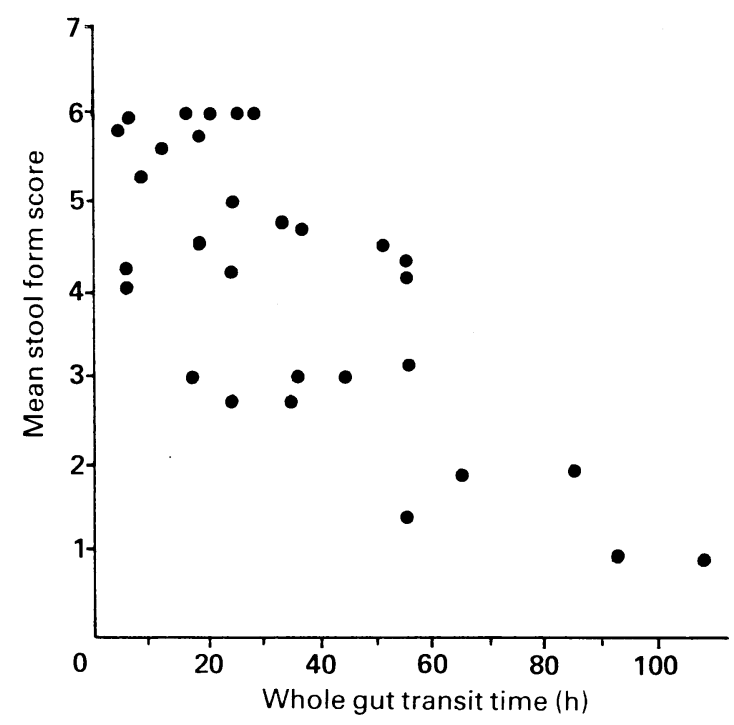

Relation between mean stool form score ( $1=$ hard lumps, $7=$ watery; see text) and whole gut transit time in patients with irritable bowel syndrome $(r=-0.77, p<0 \cdot 001)$

significant correlations between regional colonic transit time and mean stool form score, no area of the colon was particularly associated with stool form (right colon, $\mathrm{r}=-0.43, \mathrm{p}<0.05$; left colon, $\mathrm{r}=-0.62$, $\mathrm{p}<0.01$; sigmoid and rectum, $\mathrm{r}=-0.54, \mathrm{p}<0.01$ ). Urgency was recorded at least once by 22 patients. Urgency was associated with looser stools $\left(\chi^{2}\right.$ for trend $=26, \mathrm{df}=1, \mathrm{p}<0.001$ ), but the frequency of defecation was the same in patients with and without urgency (median frequency $=1.6 v 1.9 / 24 \mathrm{~h} ; \mathrm{p}=0.8$, Mann-Whitney U test).

\section{Comment}

We found that patients with the irritable bowel syndrome can keep meaningful records of stool form and that these are a reasonable guide to whole gut 